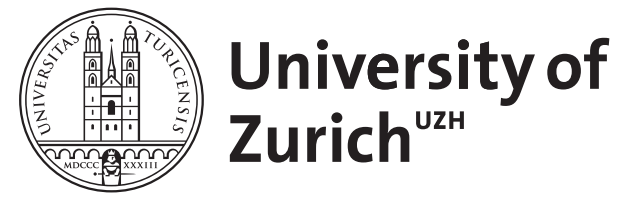

\title{
Stay-at-home fathers on the wane - In comes daddy day! Changing practices of fathering in German-speaking countries
}

\author{
Schwiter, Karin ; Baumgarten, Diana
}

\begin{abstract}
Our commentary brings Boyer et al.'s (2017) argument of a 'regendering of care' through men's growing engagement as caregivers into a dialogue with scholarship from German-speaking countries. This literature supports Boyer et al.'s claim of a connection between labour market opportunities and stayat-home fatherhood. However, the research from our language context also suggests that fathers who are not gainfully employed do not necessarily become primary caregivers. Furthermore, the number of stay-athome fathers is shrinking rather than growing. In light of these findings, we suggest shifting the discussion from stay-at-home fathers to fathers as part-time workers and part-time carers. This is where we identify the potential for a subtle revolution that bears the promise of far more wide-ranging changes in the gendering of care.
\end{abstract}

DOI: https://doi.org/10.1177/2043820617691634

Posted at the Zurich Open Repository and Archive, University of Zurich

ZORA URL: https://doi.org/10.5167/uzh-136520

Journal Article

Accepted Version

Originally published at:

Schwiter, Karin; Baumgarten, Diana (2017). Stay-at-home fathers on the wane - In comes daddy day! Changing practices of fathering in German-speaking countries. Dialogues in Human Geography, 7(1):8387.

DOI: https://doi.org/10.1177/2043820617691634 
Accepted manuscript of:

Schwiter Karin and Baumgarten Diana 2017:

Stay-at-home fathers on the wane - in comes daddy-day!

Changing practices of fathering in German-speaking countries.

in: Dialogues in Human Geography, 7(1), 83-87.

\begin{abstract}
Our commentary brings Boyer et al.'s argument of a 're-gendering of care' through men's growing engagement as caregivers into a dialogue with scholarship from Germanspeaking countries. This literature supports Boyer et al.'s claim of a connection between labour market opportunities and stay-at-home fatherhood. However, the research from our language context also suggests that fathers who are not gainfully employed do not necessarily become primary caregivers. Furthermore, the number of stay-at-home fathers is shrinking rather than growing. In light of these findings, we suggest shifting the discussion from stay-at-home fathers to fathers as part-time workers and part-time carers. This is where we identify the potential for a subtle revolution that bears the promise of far more wide-ranging changes in the gendering of care.
\end{abstract}

\title{
Keywords
}

men, care, work, fatherhood, Germany, Switzerland, Austria

\section{Text}

The last two decades have witnessed a burgeoning academic interest in shifting understandings of fatherhood and of men's involvement in unpaid care-work (Marsiglio et al., 2000; Walter and Eickhorst, 2012; Oechsle et al., 2012). But studies on stay-athome fathers (SAHFs) are rare (Peukert, 2012: 516). Kate Boyer, Esther Dermott, Al James and Julie MacLeavy review the existing literature on SAHFs from North America, Scandinavia and the UK. Their geographic focus begs the question what we could learn by extending our perspective to contexts outside the English-speaking world. It would go beyond the scope of this commentary and of our expertise to attempt an encompassing overview (cf. Levtov et al., 2015). However, we'd like to use this 
opportunity to explore how SAHFs are discussed in the German-language academic debate and reflect on what we might learn from that dialogue.

Boyer et al. (2016) argue that recessionary economic restructuring with large-scale job losses or reduced working hours might lead to more fathers becoming primary caregivers for their children and thus bring about long-term changes in the gendered division of reproductive labour. Unlike in the UK, the financial crisis of 2008/2009 did not lead to large-scale layoffs in the German-speaking countries. In Germany, unemployment rates dropped steadily from $7.4 / 7.6 \%$ in $2008 / 9$ to $4.6 \%$ in 2015 ; throughout this period, in Austria they remained below 6\% and in Switzerland below $5 \%$ (OECD, 2016b). Therefore, these periods of economic development aren't comparable.

Nevertheless, there is evidence from German research that SAHFs are indeed closely linked to labour market opportunities. Two recent studies by Klammer et al. (2012) and Klenner et al. (2012) analyse families in Germany in which mothers are the main earners. They conclude that these arrangements often do not result from choice but from necessity. The arrangements mostly emerge when fathers are unable to provide for the family due to redundancy or precarious employment. These findings are similar to those of an older study from Austria in which many SAHFs justified their arrangements by referring to previous unemployment or adverse labour market conditions (Strümpel et al. 1988 in Peukert, 2012). Similarly, Amacker (2012) discusses a Swiss case study in which stay-at-home fatherhood results from job loss. In sum, the existing literature from the German-speaking countries suggests that stay-at-home fatherhood results more from the inability of fathers to be main earners than from their desire to be primary carers (cf. also Brehmer et al., 2010).

Irrespective of the causes, Boyer et al. argue that SAHFs might include an emancipatory potential to re-gender care. Reviewing the existing research in our linguisitic region, we want to caution against imagining stay-at-home fatherhood as a straightforward role reversal. As Boyer et al. also concede, there is ample evidence that women continue to do a large share of household and care work also in SAHF-families (Klenner et al., 2012; Peukert, 2012: 516). Household and care work does not necessarily shift to the father. 
Indeed, Koppetsch and Speck (2015) find that couples tend to use various strategies that hide their deviation from the male-earner model. For example, they deliberately keep the responsibility for household and care work with the mother, they declare it a merely temporary arrangement, or they mask the father's low or inexistent earnings. Koppetsch and Speck argue that these strategies prevent disrupting SAHFs' gender identity, which is still strongly linked to employment (cf. also Scholz, 2009).

Furthermore, the evidence from the German-speaking countries does not support Boyer et al.'s UK-based findings that the number of SAHFs is growing. On the contrary, comparing the results of two independent representative surveys, Peukert (2012: 516) concludes that the share of German households with a female earner and a male carer dropped from 2\% in 1985 to $1 \%$ in 2007. According to the German statistical office the number of SAHFs did not grow between 2001 and 2011. Furthermore, in 2011, only 2\% of not-employed men between 15 and 64 years of age stated that their status resulted from care responsibilities (German Federal Statistical Office, 2012: 46). In Switzerland, $2.9 \%$ of fathers in two-parent households with children under the age of 15 were not employed. However, less than $0.5 \%$ of fathers stated that they were not in the labour market because of care responsibilities (Swiss Federal Statistical Office, 2013: 7). After a further drop in the number of SAHFs in 2013, the Swiss popular press even discussed whether the househusband was actually on the brink of extinction (Kehler, 2014).

Based on the evidence given above, we are rather critical of Boyer et al.'s argument that recession-induced SAHFs might lead to a re-gendering of care. We suspect that current shifts in the division of care work do not result from SAHFs, but from the growing number of fathers who continue their careers but reduce their working hours. In Switzerland, for example, the percentage of fathers with children under the age of 25 who work part-time has risen from 3\% in 1992 to 11\% in 2015 (Swiss Federal Statistical Office, 2016). In Austria, the share of part-time working fathers with children under 15 years of age has grown from 3.1\% in 2005 to 5.0\% in 2012 (Baierl and Kapella, 2014: 15). Similarly, in Germany, part-time workers among fathers aged 27 to 59 amounted to 5\% in 2008 (German Federal Statistical Office, 2010). 
While these numbers might not yet signify a care revolution, they gain further support from qualitative studies. In in-depth interviews on family plans with young Swiss adults in their mid-twenties, we discovered a marked shift in these adults' argumentation. Our first study consisting of 24 interviews was carried out between 2005 and 2007. The interviewees argued that they strongly support involved fatherhood and then continued to give a rationale why stay-at-home fatherhood was not a viable option for their own families (Schwiter, 2009). Talking to 46 young Swiss adults again in a second study in $2014 / 15$, we found that the interviewees were still just as skeptical with regard to stayat-home fatherhood (Baumgarten et al., in review). However, nearly all interviewees evoked the option of part-time work. Mostly, fathers' part-time work was imagined as a reduction from the standard five- to a four-day week. The interviewees argued that this day off work was important for experiencing everyday routines with their child(ren) and thus living an involved fatherhood. Simultaneously, the arrangement allowed for the mothers to increase their labour market participation.

In the popular press, this one day off work has already become a topos and is termed "daddy-day" (e.g. Mohler, 2014; Sachs, 2010; SAT3, 2016). We concede that part-time work is neither new nor revolutionary in itself. Nevertheless, we want to argue that the prevalent discussion of a daddy-day marks a major shift in the gendering of care in Switzerland. It extends the fathers' competence from shared responsibility for child-care on evenings and weekends, to being solely responsible for everyday routines with children on an ordinary workday.

Unlike stay-at-home fatherhood, however, a daddy-day does not disrupt a father's role as main earner. It only adds a second role as a part-time carer. Thus, fathers who work reduced hours do not lose their identity as breadwinners, which - as Boyer et al. indicate - is one aspect that has proven to challenging for SAHFs. To this date, male identity in Western societies has remained anchored in the sphere of work and closely associated with an employment-centered life-course (Behnke and Meuser, 2012; Baumgarten et al., 2012). Consequently, men often struggle to build a masculine identity independently of gainful employment (Scholz, 2009; Peukert, 2012: 523f; Hanlon, 2009: 193). Considering the persisting stigmas of unemployment and of housework as 
feminised work, this is not surprising. In contrast to SAHFs, fathers working as four-day earners and one-day carers can evade this fundamental challenge to their identities.

There are some caveats, of course. First, more research is needed to find out whether daddy-days are prevalent throughout society or limited to specific socio-economic and geographic milieus. Due to the persisting gap between women's and men's wages (OECD, 2016a), reducing a father's working hours in exchange for an increase in the mother's share, will in most couples result in a net financial loss. Even in a comparably well-off country like Switzerland, a reduction of income will not be easily affordable for all families.

Furthermore, we agree with Boyer et al. that a great deal of research still needs to be done on men who are part-time workers and part-time carers. We need to know more about how these daddy-days are negotiated and lived in the respective families. Do mothers prepare meals, get gym bags ready, and write a to-do list for the fathers? Do fathers remain the mothers' "junior partners" (Behnke and Meuser, 2012: 131) and "perpetual trainees" (Jurczyk and Lange, 2012: 13)? Or do they become equal partners in caring? Do daddy-days consist of mainly play-and-fun or do they also generate a marked shift in the allocation of housework (cf. König, 2012)? How does bearing sole responsibility for workday routines with children shape these fathers' identities? Does caring become an integral part of male identity and bring about a broadened understanding of masculinity (Behnke and Meuser, 2012)?

In sum, we suggest refocusing the debate away from SAHFs to fathers as part-time workers and part-time carers, because this is where we see the need for more research and a great potential for a subtle revolution regarding the gendering of care.

\section{Acknowledgements}

We wish to thank our colleagues Nina Wehner, Andrea Maihofer, Karsten Kassner und Matthias Lutherbach for many years of inspiring collaboration in studying the changing practices of fatherhood, as well as Anne Zimmermann for her valuable comments on earlier versions of this paper. We are grateful to the Swiss National Science Foundation 
and the core team of the National Research Programme 60 for their funding and support.

\section{References}

Amacker M. (2012) „Und seit dann bin ich einfach daheim, Modell Hausmann.“ Prekäre Konstellationen: Lebensführung von Haushalten in prekären Lebenslagen zwischen Erwerbs- und Care-Arbeit ("And since then, I've just been at home, style househusband." Precarious constellations: how households in precarious circumstances organize their lives between employment and care work). In: Moser V and Rendtorff B (eds) Riskante Leben? Geschlechterordnungen in der Reflexiven Moderne. Opladen: Barbara Budrich, 65-80.

Baierl A and Kapella O. (2014) Trend zur Teilzeit (A trend towards part-time work), Vienna: Working Paper Nr. 81 des Österreichischen Instituts für Familienfoschung der Universität Wien.

Baumgarten D, Kassner K, Maihofer A, et al. (2012) Warum werden manche Männer Väter, andere nicht? Männlichkeit und Kinderwunsch (Why do some men become fathers and not others? Masculinity and the desire to have children). In: Walter $\mathrm{H}$ and Eickhorst A (eds) Das Väter-Handbuch. Theorie, Forschung, Praxis. Giessen: Psychosozial-Verlag, 415- 443.

Baumgarten D, Wehner N, Maihofer A, et al. (in review) „Wenn Vater, dann will ich Teilzeit arbeiten“ Die Verknüpfung von Berufs- und Familienvorstellungen bei 30jährigen Männern aus der deutschsprachigen Schweiz. ("If I become a father, I want to work part-time." The nexus of career and family plans of 30-year-old men from German-speaking Switzerland) submitted to GENDER - Zeitschrift für Geschlecht, Kultur, Gesellschaft.

Behnke C and Meuser M. (2012) "Look here mate! I'm taking parental leave for a year" involved fatherhood an images of masculinity In: Oechsle M, Müller U and Hess S (eds) Fatherhood in Late Modernity. Cultural Images, Social Pracices, Structural Frames. Opladen: Barbara Budrich, 129-145.

Boyer K, Dermott E, James A, et al. (forthcoming) Regendering care in the aftermath of recession. Dialogues in Human Geography. 
Brehmer W, Klenner C and Klammer U. (2010) Wenn Frauen das Geld verdienen - eine empirische Annäherung an das Phänomen der „Familienernährerin“ (When women earn the money - an empirical approach to the phenomenon of the "female breadwinner"), Düsseldorf: Diskussionspapier Nr. 170 des Wirtschaftsund Sozialwissenschaftlichen Instituts der Hans Böckler Stiftung.

German Federal Statistical Office. (2010) Frauen und Männer in verschiedenen Lebensphasen (Women and men in different phases of life ), Wiesbaden: Statistisches Bundesamt.

German Federal Statistical Office. (2012) Frauen und Männer auf dem Arbeitsmarkt (Women and men in the labour market), Wiesbaden: Statistisches Bundesamt. Hanlon N. (2009) Masculinities and Affective Equality: Love Labour and Care Labour in Men's Live. GEXCEL Work in Progress Report 4: 191-199.

Jurczyk K and Lange A. (2012) Vom "ewigen Praktikanten" zum "reflexiven Vater"? Eine Einführung in aktuelle Debatten um Väter (From the "perpetual trainee" to the "reflexive father"? An introduction to current debates on fathers). In: Jurczyk K and Lange A (eds) Vaterwerden und Vatersein heute. Neue Wege - Neue Chancen! Gütersloh: Bertelsmann Stiftung, 13-43.

Kehler K. (2014) «Das bisschen Haushalt»: Schweizer Hausmann stirbt aus. ("That bit of household": The extinction of the Swiss househusband) Familienleben online issue of 24.02.2016.

Klammer U, Neukirch S and Weßler-Poßberg S. (2012) Wenn Mama das Geld verdient. Familienernährerinnen zwischen Prekarität und neuen Rollenbildern (When mummy earns the money. Female breadwinners between precariousness and new role models), Berlin: edition sigma.

Klenner C, Menke K and Pfahl S. (2012) Flexible Familienernährerinnen. Moderne Geschlechterarrangements oder prekäre Konstellationen? (Flexible female breadwinners. Modern gender arrangements or precarious constellations?), Opladen: Barbara Budrich.

König T. (2012) Familie heißt Arbeit teilen. Transformationen der symbolischen Geschlechterordnung (Having a family means sharing work. Transformation of the symbolic order of sexes), Konstanz: Universitätsverlag Konstanz. 
Koppetsch C and Speck S. (2015) Wenn der Mann kein Ernährer mehr ist -

Geschlechterkonflikte in Krisenzeiten (When the man is no longer a breadwinner Gender conflicts in times of crisis), Berlin: Suhrkamp.

Levtov R, van der Gaag N, Greene M, et al. (2015) State of the World's Fathers

Washington, DC: Promundo, Rutgers, Save the Children, Sonke Gender Justice and the MenEgage Alliance.

Marsiglio W, Amato P, Day RD, et al. (2000) Scholarship on Fatherhood in the 1990s and Beyond. Journal of Marriage and the Family 62: 1173-1191.

Mohler N. (2014) Mittwoch ist Papa-Tag. (Wednesday is daddy-day) Der Arbeitsmarkt issue $3 / 2014:$ 5-9.

OECD. (2016a) Gender wage gap: https://www.oecd.org/gender/data/genderwagegap.htm, accessed 08.07.2016.

OECD. (2016b) Harmonised Unemployment Rates: http://stats.oecd.org/index.aspx?queryid=36324\#, accessed 28.06.2016.

Oechsle M, Müller U and Hess S. (2012) Fatherhood in Late Modernity. Cultural Images, Social Pracices, Structural Frames Opladen: Barbara Budrich.

Peukert R. (2012) Familienformen im sozialen Wandel (Family models undergoing social change), Wiesbaden: Springer.

Sachs S. (2010) Heute ist Papa-Tag. Wenn Männer Teilzeit arbeiten. (Today is daddyday. When men work part-time) ECO - das Wirtschaftsmagazin des Schweizer Fernsehns SRF first broadcasted on 25.10.2010.

SAT3. (2016) Freitag ist Papatag. Väter wollen mehr als nur Ernährer sein. (Friday is daddy-day. Fathers want to be more than just breadwinners) Science Programme Nano first broadcasted on 15.08.2015.

Scholz S. (2009) Männer und Männlichkeiten im Spannungsfeld zwischen Erwerbs- und Familienarbeit (Men and masculinities caught between employment and family work). In: Aulenbacher B and Wetterer A (eds) Arbeit. Perspektiven und Diagnosen der Geschlechterforschung. Münster: Westfälisches Dampfboot.

Schwiter K. (2009) „Ich würde gerne den Hausmann spielen..." Gute und schlechte Väter in den Erzählungen junger Erwachsener ("I'd love to play the househusband" Good and bad fathers in the narratives of young adults). In: Villa P-I and Thiessen B (eds) Mütter - Väter: Diskurse, Medien, Praxen. Münster: Westfälisches Dampfboot, 213-225. 
Swiss Federal Statistical Office. (2013) Das Engagement der Väter in Haushalt und Familie (Fathers' engagement in household and family), Neuchâtel: Swiss Federal Statistical Office.

Swiss Federal Statistical Office. (2016) Erwerbsbeteiligung von Müttern und Vätern (Mothers' and fathers' labour market participation): http://www.bfs.admin.ch/bfs/portal/de/index/themen/20/05/blank/key/Vere inbarkeit/01.html, accessed: 06.07.2016.

Walter H and Eickhorst A. (2012) Das Väter-Handbuch. Theorie, Forschung, Praxis (The father handbook. Theory, research and practice), Giessen: Psychosozialverlag. 